\title{
PENERAPAN MODEL DISCOVERY LEARNING PADA MATERI KELARUTAN DAN HASIL KALI KELARUTAN UNTUK MENINGKATKAN PRESTASI BELAJAR DAN KETERAMPILAN GENERIK SAINS KELAS XI IPA SMA NEGERI 2 SUKOHARJO TAHUN PELAJARAN 2017/2018
}

\author{
Faradilla Prima Hesti, ${ }^{*}$ Sri Retno Dwi Ariani, dan Bakti Mulyani \\ Program Studi Pendidikan Kimia, FKIP, Universitas Sebelas Maret, Surakarta, Indonesia \\ “Keperluan korespondensi, telp: +6285783602213, e-mail: faradilaprimahesti@gmail.com
}

\begin{abstract}
ABSTRAK
Penelitian ini bertujuan untuk meningkatkan: (1) keterampilan generik sains dalam materi Kelarutan dan Hasil Kali Kelarutan (Ksp) melalui implementasi pembelajaran kimia Kelas XI IPA SMA Negeri 2 Sukoharjo Tahun Pelajaran 2017/2018 dengan model pembelajaran Discovery Learning; (2) prestasi belajar dalam materi Kelarutan dan Hasil Kali Kelarutan (Ksp) melalui implementasi pembelajaran kimia Kelas XI IPA SMA Negeri 2 Sukoharjo Tahun Pelajaran 2017/2018 dengan model pembelajaran Discovery Learning. Penelitian ini merupakan penelitian tindakan kelas yang dilaksanakan dalam 2 siklus pada kelas XI IPA 2 SMA Negeri 2 Sukoharjo. Tahapan siklus terdiri atas tahap perencanaan, pelaksanaan tindakan, observasi dan refleksi pada setiap siklusnya. Subyek penelitian adalah siswa kelas XI IPA 2 SMA Negeri 2 Sukoharjo. Data dan sumber data yang digunakan diperoleh dari guru, siswa dan dokumentasi. Teknik pengumpulan data meliputi tes, observasi dan angket. Berdasarkan hasil penelitian disimpulkan bahwa model pembelajaran Discovery Learning dapat meningkatkan: keterampilan generik sains pada materi kelarutan dan hasil kali kelarutan. Hal tersebut terlihat pada kenaikan prasiklus sebesar $29 \%$ menjadi menjadi $50 \%$ pada siklus I dan $72 \%$ pada siklus II. (2) Prestasi belajar siswa pada materi kelarutan dan hasil kali kelarutan (aspek pengetahuan pada siklus I adalah $53 \%$ meningkat menjadi $83 \%$ pada siklus II, aspek sikap presentase ketercapaian siswa di siklus I 96\% dan meningkat pada siklus II menjadi 100\%, pada aspek keterampilan siklus I ketercapaian ketuntasan siswa mencapai nilai maksimum yaitu 100\%).
\end{abstract}

Kata kunci: Keterampilan Generik Sains, Prestasi Belajar, Discovery Learning, Kelarutan dan Hasil Kali Kelarutan

\section{PENDAHULUAN}

Indonesia merupakan salah satu negara berkembang yang sedang memperbaiki segala bidang demi mengikuti globalisasi yang semakin maju, slah satunya bidang pendidikan atau pembelajaran. Pembelajaran merupakan suatu kegiatan yang dilaksanakan di dalam kelas dengan melibatkan siswa dan pendidik. Pembelajaran akan berjalan dengan baik apabila kedua komponen tersebut saling mendukung dan bekerjasama dalam kegiatan belajar mengajar. Menurut Permendikbud No.160 tahun 2014, pembelajaran adalah proses interaksi antar siswa, antara siswa dengan pendidik dan sumber belajar pada suatu lingkungan belajar [10]. Pembaruan kurikulum merupakan usaha terencana yang mengarah pada terwujudnya proses pembelajaran yang lebih baik.

Kimia adalah satu pelajaran yang ada di kelas XI IPA yang menuntut siswa aktif dalam pembelajaran. Kimia seharusnya menjadi mata pelajaran yang menyenangkan karena memiliki kaitan erat dengan peristiwa di alam sehingga dapat dengan mudah ditemui dalam kehidupan sehari-hari seperti materi kelarutan dan hasil kali kelarutan. Dalam penerapan kurikulum 2013 materi kelarutan dan hasil kali kelarutan ini terdapat di kelas XI semester genap. 
Berdasarkan data nilai dan wawancara, serta observasi yang diperoleh menunjukkan bahwa pada pembelajaran kimia, siswa yang menguasai materi ini tidak semua mencapai batas ketuntasan yang ditetapkan dan dapat dikatakan masih rendah. Hal ini dapat dilihat dari prestasi belajar siswa selama 3 tahun terakhir yang diperoleh dari aplikasi hasil ujian nasional (UN) dan nilai ujian sekolah (UAS) pelajaran kimia di SMA Negeri 2 Sukoharjo pada tabel 1. Permasalahan lain yang terjadi adalah siswa kurang antusias dan aktif ketika proses pembelajaran, sehingga dalam proses pembelajaran siswa cenderung pasif, terlebih siswa memiliki pondasi dasar pemikiran yang menyatakan kimia pelajaran sulit.

Tabel 1. Prestasi Belajar Siswa 3 Tahun Terakhir ujian nasional (UN) dan nilai ujian sekolah (UAS) SMA Negeri 2 Sukoharjo

\begin{tabular}{ccc}
\hline $\begin{array}{c}\text { Tahun } \\
\text { Pelajaran }\end{array}$ & $\begin{array}{c}\text { Nilai } \\
\text { Sekolah }\end{array}$ & Nasional \\
\hline $2013 / 2014$ & 37,41 & 56,77 \\
$2014 / 2015$ & 69,80 & 63,65 \\
$2015 / 2016$ & 57,65 & 47,20 \\
\hline
\end{tabular}

Dalam Kurikulum 2013 yang berdasarkan kompetensi dan karakter memiliki tujuan dan harapan ingin mengubah pola pendidikan dari orientasi terhadap hasil dan materi ke pendidikan sebagai proses, melalui suatu pendekatan tematik integrative dengan contextual teaching and learning (CTL) [3]. Penerapan Kurikulum K13 siswa dituntut lebih aktif dalam proses pembelajaran serta mampu berinteraksi dengan lingkungan untuk mendapatkan informasi-informasi yang dibutuhkan. Sesuai dengan permendikbud Nomor 65 Tahun 2013 tentang Standar Proses menyebutkan bahwa model yang diutamakan pada implementasi $\mathrm{K} 13$ adalah model pembelajaran Inquiry, Discovery Learning, Project Based Learning, dan Problem based Learning.

Discovery Learning merupakan suatu pembelajaran yang melibatkan peserta didik dalam pemecahan masalah untuk pengembangan pengetahuan dan ketrampilan [1]. Hal ini menunjukkan pembelajaran discovery dapat meningkatkan pemahaman siswa terhadap pengetahuan sebelumnya serta meningkatkan aktivitas siswa dan dapat meningkatkan keberhasilan belajar siswa. Pembelajaran discovery melalui kegiatan laboratorium dapat meningkatkan hasil belajar kimia siswa. Melalui kegiatan laboratorium diharapkan siswa memiliki hasil belajar sains berupa kemampuan berfikir dan bertindak berdasarkan pengetahuan sains yang dimilikinya, atau lebih dikenal sebagai keterampilan generik sains.

Pokok pada materi Kelarutan dan Hasil Kali Kelarutan (Ksp) merupakan materi yang sulit karena memiliki karakteristik pemahaman konsep dan kemampuan matematis dan memiliki keterkaitan terhadap materi sebelumnya. Melalui kegiatan laboratorium diharapkan siswa memiliki hasil belajar sains berupa kemampuan berfikir dan bertindak berdasarkan pengetahuan sains yang dimilikinya, atau lebih dikenal sebagai keterampilan generik sains. Keterampilan generik sains merupakan suatu kemampuan dasar yang bersifat umum dan dapat dikembangkan melalui proses pembelajaran konsep-konsep kimia [11]. Keterampilan generik menjadi suatu yang bersifat umum, karena implementasinya memberikan kesuksesan sesuai dengan bidang masing-masing khususnya dalam bidang sains. Adapun indikator kemampuan generik sains yang dapat diterapkan diantaranya kemampuan melakukan pengamatan langsung dan tak langsung, bahasa simbolik, kesadaran akan skala, inferensi logika, hukum sebab akibat, pemodelan matematika dan hal-hal lain yang melandasinya [6]. Keterampilan generik menjadi suatu yang bersifat umum, karena implementasinya memberikan kesuksesan sesuai dengan bidang masing-masing khususnya dalam bidang sains [7]. Data hasil uji pelaksanaan prasiklus yang dilakukan di SMA $\mathrm{N} 2$ Sukoharjo menunjukkan presentasi hasil kelulusan aspek ketarampilan generik sains siswa hanya $29 \%$. Ini menunjukkan bahwa keterampilan generik sains siswa juga masih rendah. 
Faktor yang mempengaruhi keberhasilan prestasi belajar siswa diteliti dalam penelitian ini antara lain model pembelajaran dan keterampilan generik sains. Dalam hal ini, model pembelajaran merupakan salah satu contoh dari faktor eksternal, sedangkan keterampilan generik sains merupakan factor internal yang mempengaruhi keberhasilan prestasi belajar siswa.

Berdasarkan uraian di atas maka perlu dilakukan Penelitian Tindakan Kelas (PTK) untuk meningkatkan prestasi belajar siswa dan keterampilan generik sains. Maka dari itu penulis melakukan penelitian yang berjudul, "Penerapan Model Discovery Learning pada Materi Kelarutan dan Hasil Kali Kelarutan untuk Meningkatkan Prestasi Belajar dan Keterampilan Generik Sains Kelas Xi IPA SMA Negeri 2 Sukoharjo Tahun Pelajaran 2017/2018".

\section{METODE PENELITIAN}

Metode penelitian yang digunakan adalah penelitian tindakan kelas (PTK) yang dilaksanakan dalam dua siklus. Setiap siklus terdiri dari empat tahap yaitu tahap perencanaan, pelaksanaan tindakan, observasi dan refleksi. Penelitian ini dilaksanakan dalam 8 bulan mulai dari perencanaan hingga penyusunan laporan. Penelitian ini dilaksanakan di SMA Negeri 2 Sukoharjo kelas XI IPA tahun pelajaran 2017/2018. Subjek penelitian ini adalah siswa kelas XI IPA 2 semester genap SMA Negeri 2 Sukoharjo. Objek penelitiannya meliputi keterampilan generik sainsdan prestasi belajar siswa.

Data penelitian yang dikumpulkan terdiri dari data kuantitatif berupa hasil tes dan data kualitatif meliputi hasil wawancara dan observasi dengan guru dan siswa. Sumber data yang diperoleh dari informan (guru dan siswa), peristiwa dan dokumen (silabus, RPP, LKPD, dan angket). Sedangkan pengumpulan data menggunakan metode tes dan non tes. Instrumen dalam penelitian ini meliputi instrumen pembelajaran dan penilaian dengan menggunakan uji validas Gregorry, sedangkan uji reliabilitas menggunakan aplikasi ITEMAN dan aplikasi
SPSS. Teknik analisis data dilakukan secara kualitatif berdasarkan model analisis Milles \& Huberman dalam tiga komponen yaitu reduksi, penyajian data dan penarikan kesimpulan dan perifikasi [8]. Indikator hasil capaian digunakan sebagai tolak ukur keberhasilan yang ingin dicapai disesuaikan dengan ketentuan sekolah dan digambarkan dalam Tabel 2 berikut ini.

Tabel 2. Aspek Ketuntasan Siswa Siklus I

\begin{tabular}{lc}
\hline \multicolumn{1}{c}{$\begin{array}{c}\text { Aspek yang } \\
\text { diukur }\end{array}$} & $\begin{array}{c}\text { Persentase } \\
\text { Ketuntasan } \\
\text { Siswa Siklus I }\end{array}$ \\
\hline Pengetahuan & 70 \\
Sikap & 70 \\
Keterampilan & 70 \\
Keterampilan & 70 \\
Generik Sains & \\
\hline
\end{tabular}

\section{HASIL DAN PEMBAHASAN}

Penelitian ini merupakan penelitian tindakan kelas (PTK). Penelitian ini bertujuan untuk mengembangkan kemampuan siswa dengan keterampilan generik sains dalam proses pembelajaran. Penelitian tindakan kelas ini dilakukan dalam dua siklus. Siklus I dilaksanakan selama empat kali pertemuan dimana satu pertemuan terakhir digunakan untuk evaluasi dan siklus II dilaksanakan dua kali pertemuan yaitu pertemuan untuk mengulas materi dan evaluasi.

\section{Siklus I}

Perencanaan tindakan dalam siklus I meliputi penyusunan instrumen pembelajaran dan instrumen penilaian. Instrumen pembelajaran tersebut adalah silabus dan RPP. Sedangkan instrumen penilaiannya adalah penilaian aspek pengetahuan, sikap, keterampilan dan keterampilan generik sains siswa.

Pelaksanaan tindakan siklus I kegiatan pembelajaran yang dilakukan pada siklus I ini direncanakan selama 8 jam pembelajaran (JP), yaitu 6 JP untuk penyampaian materi dan praktikum, serta 2 JP untuk melakukan evaluasi. Dalam setiap pertemuan siswa belajar dalam kelompok dalam memecahkan permasalahan yang diberikan yang berkaitan dengan materi pokok yang 
disampaikan. Penilaian aspek sikap dan keterampilan dilakukan saat kegiatan pembelajaran berlangsung dengan menggunakan metode observasi. Dalam proses penilaian sikap, selain menggunakan metode observasi peneliti juga menggunakan penilaian dengan metode angket. Untuk penilaian keterampilan sains dan pengetahuan dilakukan saat evaluasi akhir pertemuan.

Tabel 3. Presentase Jumlah Siswa yang Tuntas pada Aspek Pengetahuan di Siklus I Berdasarkkan Indikator Kompetensi

\begin{tabular}{lcc}
\hline $\begin{array}{c}\text { Indikator } \\
\text { Kompetensi }\end{array}$ & $\begin{array}{c}\text { Target } \\
(\%)\end{array}$ & $\begin{array}{c}\text { Capaian } \\
(\%)\end{array}$ \\
\hline IK I & 70 & 77,78 \\
IK 2 & 70 & 65,28 \\
IK 3 & 70 & 51,85 \\
IK 4 & 70 & 43,52 \\
Rata-rata & 70 & 59,61 \\
\hline
\end{tabular}

Pada siklus I hasil belajar aspek pengetahuan ketuntasan yang tercapai hanya $53 \%$ dengan persentase ketuntasan setiap indikator masih tergolong rendah yaitu pada indikator kompetensi pertama (Menjelaskan kesetimbangan dalam larutan jenuh atau larutan garam yang sukar larut) sudah $77,78 \%$, indikator kedua (Menghubungkan tetapan hasil kali kelarutan dengan tingkat kelarutan) $65,28 \%$, indikator ketiga (Memperkirakan pengendapan dari hasil perhitungan) sebesar $51,85 \%$ dan indikator kompetensi keempat (Menjelaskan pengaruh ion senama dan $\mathrm{pH}$ pada kelarutan) hanya $43,52 \%$. Sedangkan batas ketuntasan yang ditetapkan adalah $70 \%$.

Tabel 4. Presentase Jumlah Siswa yang Tuntas pada Aspek Keterampilan Generik Sains (KGS) di Siklus I

\begin{tabular}{ccc}
\hline Indikator & Target(\%) & Capaian(\%) \\
\hline Indikator 1 & 70 & 54 \\
Indikator 2 & 70 & 55,5 \\
Indikator 3 & 70 & 80,5 \\
Indikator 4 & 70 & 76,5 \\
Indikator 5 & 70 & 54 \\
\hline
\end{tabular}

Pada aspek keterampilan generik sains (KGS) siswa pada siklus I memiliki presentase sebesar $64,1 \%$. Rata-rata tertinggi didapatkan pada indikator kemampuan menyelesaikan masalah dengan presentase sebesar $80,5 \%$ dan rata-rata terendah pada indikator kemampuan kerjasama tim dan keterampilan berkomunikasi beretika dengan presentase sebesar $54 \%$. Pada keterampilan menganalisis presentase sebesar $55,5 \%$ dan keterampilan berfikir kritis sebesar $76,5 \%$. Target ketuntasan siswa yang ingin dicapai adalah $60 \%$. Berdasarkan hasil capaian siswa pada keterampilan generik sains diketahui siswa yang mencapai ketuntasan hanya sebesar $50 \%$ yang mencapai ketuntasan. Hasil penilaian tindakan selama siklus I dapat dilihat dari Tabel 5.

Tabel 5. Hasil Capaian pada Siklus I

\begin{tabular}{lcc}
\hline \multicolumn{1}{c}{ Aspek } & $\begin{array}{c}\text { Capaian } \\
(\%)\end{array}$ & Kriteria \\
\hline Pengetahuan & 53 & BT \\
Sikap & 96 & $\mathrm{~T}$ \\
Keterampilan & 100 & $\mathrm{~T}$ \\
Keterampilan & 50 & $\mathrm{BT}$ \\
generik sains & & \\
${ }^{*}$ BT : Belum Tuntas, $\mathrm{T}$ : Tuntas &
\end{tabular}

Berdasarkan data pada siklus I diketahui bahwa aspek sikap dan keterampilan sudah mencapai ketuntasan dengan persentase $96 \%$ dan $100 \%$. Hal ini menunjukkan hasil pembelajaran yang telah dilakukan pada siklus I diketahui bahwa target ketuntasan dalam penelitin belum tercapai pada aspek pengetahuan dan keterampilan generik sains maka perlu dilakukan perbaikan pembelajaran dengan melanjutkan tindakan siklus II guna meningkatkan hasil belajar yang ingin dicapai.

\section{Siklus II}

Pada siklus II materi yang dibahas difokuskan pada indikator kompetensi yang belum tuntas pada siklus I. Karena pada siklus I terdapat tiga indikator yang belum tuntas pada siklus I dan dilihat berdasar ketuntasan indikator soal pada satu indikator lain dalam siklus I maka pada indikator tersebut akan dibahas pada siklus II. Selain itu siklus II ini bertujuan untuk memperbaiki dan 
menyempurnakan kendala yang terjadi pada siklus I.

Pembelajaran pada siklus II dilakukan selama $4 \mathrm{JP}$, yaitu $2 \mathrm{JP}$ untuk penyampaian materi dengan indikator kompetensi yang belum tuntas dan $2 \mathrm{JP}$ sisanya digunakan untuk evaluasi ulang apakah ada perubahan atau peningkatan pada siklus II tersebut. Adapun rangkuman hasil penilaian tindakan selama siklus II terdapat pada Tabel 6 .

Tabel 6. Hasil Capaian pada Siklus II

\begin{tabular}{ccc}
\hline Aspek & $\begin{array}{c}\text { Capaian } \\
(\%)\end{array}$ & Kriteria \\
\hline Pengetahuan & $83 \%$ & Tuntas \\
Keterampilan & $72 \%$ & Tuntas \\
generik Sains & & \\
\hline
\end{tabular}

Berdasarkan hasil target ketercapaian dari kedua aspek pada siklus II yang disajikan Tabel 3, dapat disimpulkan bahwa pelaksanaan model pembelajaran Discovery Learning di kelas XI IPA 2 SMA Negeri 2 Sukoharjo pada materi kelarutan dan hasil kali kelarutan ini telah berhasil. Penelitian tindakan kelas ini diakhiri pada siklus II karena prestasi belajar dan kemampuan literasi sains yang diukur telah mencapai target yang ditentukan.

\section{Perbandingan Hasil Tindakan Antar- siklus}

\section{a. Keterampilan Generik Sains}

Keterampilan generik sains siswa diukur dengan menggunakan tes. Dari hasil tes tersebut dibandingkan adakah peningkatan yang terjadi antara siklus I dengan siklus II. Setelah data nilai diolah, diketahui bahwa terjadi peningkatan pada siklus II yaitu pada siklus I hanya 18 siswa atau $50 \%$ siswa yang tuntas. Sedangkan pada siklus II sudah 26 siswa atau $72 \%$ siswa mencapai ketuntasan. Ringkasan hasil capaian Keterampilan generic sains siswa dapat diihat pada Tabel 7 dan Gambar 1.

Hal ini didukung berdasarkan penelitian yang dilakukan Febrianti yang menyatakan bahwa model pembelajaran berbasis problem solving dapat meningkatkan keterampilan generik sains siswa pada indikator kerjasama dan pemeca- han masalah [4]. Hal ini sesuai dengan penelitian dalam jurnal yang ditulis Hande \& Kommattil yang menjelaskan bahwa pembelajaran berbasis masalah dapat meningkatkan pengetahuan, keterampilan generik sains dan sikap [5]. Ungkapan lain disampaikan oleh Curtis \& Denton dengan menyarankan hal serupa bahwa apabila ingin meningkatkan keterampilan generik sains, maka pendekatan pembelajaran yang digunakan sebaiknya adalah pembelajaran berbasis pemecahan masalah dan/atau menyajikan masalah sehingga siswa diajak untuk menemukan pengetahuannya sendiri [2]. Mercer-mapstone \& Kuchel juga menyebutkan bahwa pembelajaran dengan pendekatan praktik langsung (presentasi, diskusi, pengisian lembar individu/kelompok). Hal ini dapat menguatkan hasil penelitian yang dilakukan bahwa penerapan model pembelajaran Discovery Learning dapat meningkatkan keterampilan generik sains siswa.

Tabel 7. Persentase Jumlah Siswa yang Tuntas pada Aspek Keterampilan Generik Sains (KGS) tiap Indikator

\begin{tabular}{lcc}
\hline \multirow{2}{*}{ Indikator } & \multicolumn{2}{c}{ Capaian(\%) } \\
\cline { 2 - 3 } & Siklus I & Siklus II \\
\hline Kerja Tim & 54 & 76.4 \\
Menganalisis & 55,5 & 81,95 \\
Menyelesaikan & 80,5 & - \\
Masalah & & \\
Berfikir Kritis & 76,5 & - \\
Berkomunikasi & 54 & 79,17 \\
Rata-Rata & 64,1 & 79,17 \\
\hline
\end{tabular}

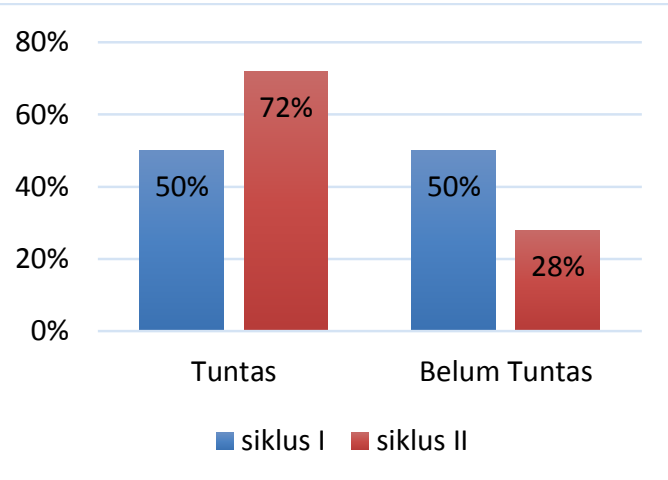

Gambar 1. Persentase Jumlah Siswa yang Tuntas Aspek Keterampilan Generik Sains pada Siklus I dan Siklus II 


\section{b. Prestasi belajar}

Prestasi belajar aspek pengetahuan ditentukan berdasarkan seberapa besar persentase ketuntasan siswa pada materi kelarutan dan hasil kali kelarutan.

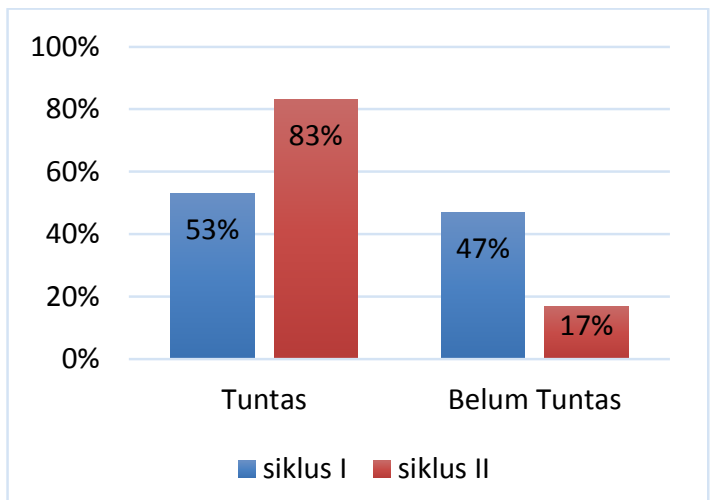

Gambar 2. Persentase Jumlah Siswa yang Tuntas Aspek Pengetahuan pada Siklus I dan Siklus II

Dalam penelitian tindakan kelas ini, tes pengetahuan digunakan sebagai alat ukur prestasi siswa pada aspek pengetahuan yang dilakukan di akhir siklus I maupun siklus II. Tes ini menggunakan soal-soal objektif. Perbandingan hasil tes antarsiklus dapat dilihat pada Gambar 2.

Pada siklus I terdapat tiga indikator yang belum tuntas pada siklus I dan dilihat berdasar ketuntasan indikator soal pada satu indikator lain dalam siklus I. Sehingga penelitian dilanjutkan pada siklus II, dan diperoleh bahwa di siklus II ini sudah mencapai ketuntasan. Apabila dilihat dari hasil ketuntasan pada siklus I terdapat 19 dari 36 siswa telah tuntas dalam kelas XI IPA 2 atau sebesar 53\%. Sedangkan 17 siswa lainnya belum mancapai target ketuntasan. Persentase ketuntasan siswa tersebut belum mencapai target yaitu $70 \%$ yang diiharapkan.

Tabel 8. Persentase Jumlah Siswa yang Tuntas Aspek Pengetahuan pada Siklus I dan Siklus II berdasarkan indikator kompetensi

\begin{tabular}{lcc}
\hline \multirow{2}{*}{ Kategori } & \multicolumn{2}{c}{ Capaian (\%) } \\
\cline { 2 - 3 } & Siklus I & Siklus II \\
\hline IK 1 & 77,78 & 80,56 \\
IK 2 & 65,28 & 75,00 \\
IK 3 & 51,85 & 76,39 \\
IK 4 & 43,52 & 77,78 \\
Rata-rata & 59,61 & 77,43 \\
\hline
\end{tabular}

Keterangan Indikator Kompetensi

IK 1: Menjelaskan kesetimbangan dalam larutan jenuh atau larutan garam yang sukar larut

IK 2 : Menghubungkan tetapan hasil kali kelarutan dengan tingkat kelarutan

IK 3 : Memperkirakan pengendapan dari hasil perhitungan

IK 4 : Menjelaskan pengaruh ion senama dan $\mathrm{pH}$ pada kelarutan

Dari hasil tes yang dilakunan di siklus II yang dilakukan pada akhir pembelajaran siklus II diketahui bahwa ketuntasan siswa mencapai $83 \%$ yaitu sekitar 30 siswa yang telah tuntas. Hal tersebut menunjukkan bahwa terjadi peningkatan dari siklus I ke siklus II dan persentase ketuntasan siswa telah mencapai target yang diharapkan. Berikut disajikan data mengenai ketuntasan prestasi siswa pada aspek pengetahuan dalam siklus I dan siklus II pada Tabel 9.

Tabel 9. Persentase Jumlah Siswa yang Tuntas pada Aspek Pengetahuan Siklus I dan Siklus II

\begin{tabular}{lcc}
\hline \multirow{2}{*}{ Kategori } & \multicolumn{2}{c}{ Capaian (\%) } \\
\cline { 2 - 3 } & Siklus I & Siklus II \\
\hline Tuntas & $53 \%$ & $83 \%$ \\
Belum & $47 \%$ & $17 \%$ \\
Tuntas & & \\
\hline
\end{tabular}

Hasil tersebut didukung oleh pernyataan depdiknas tahun 2005 yang menjelaskan bahwa penerapan model discovery learning dalam IPA diduga dapat memberikan konstribusi terhadap masalah-masalah pembelajaran IPA yang dialami siswa, khususnya dalam peningkatan pemahaman konsep-konsep maupun pengembangan sikap ilmiah. Sebelumnya telah dilakukan penelitian yang yang membuktikan bahwa perbedaanperbedaan antara model discovery learning dan model pengajaran langsung diyakini memberikan efek yang berbeda terhadap pemahaman konsep IPA dan sikap ilmiah siswa [9].

\section{KESIMPULAN}

Berdasarkan hasil penelitian yang telah dilakukan di dalam kelas XI IPA 2 
maka dapat disimpulkan bahwa: penerapan model pembelajaran Discovery Learning dapat meningkatkan prestasi belajar dan keterampilan generik sains siswa pada materi redoks siswa kelas XI IPA 2 SMA Negeri 2 Sukoharjo tahun pelajaran 2017/2018.

\section{UCAPAN TERIMA KASIH}

Penelitian ini dapat terselesaikan dengan baik karena bantuan dari berbagai pihak. Oleh karena itu penulis mengucapkan terimakasih kepada kelapa SMA Negeri 2 Sukoharjo yang telah memberikan izin dilakukannya penelitian di sekolah tersebut, guru kimia dan seluruh siswa kelas XI IPA 2 yang telah banyak membantu dalam proses menyelesaikan penelitian.

\section{DAFTAR RUJUKAN}

[1] Anitah, S. (2013).Teknologi Pembelajaran. Surakarta: Yuma Pustaka.

[2] Curtis, D., \& Denton, R. (2003). The Authentic performance-based assessment of Problem-Solving generic Skills. NCVER. Australia: NCVER.

[3] Dimyati \& Mudjiono. (2013). Belajar dan Pembelajaran. Jakarta: Rineka Cipta.

[4] Febriyanti, D., llyas, S., \& Nurmaliah, C. (2014). Peningkatan Keterampilan Generic Saina melalui Penerapan Model SSCS (Search, Solve, Create and Share) pada Materi Mengklasifikasikan Mahluk Hidup di MTs N Model Banda aceh. Jurnal Biologi Edukasi. 6(2), 43-47.

[5] Hande S, Mohammed C.A., and Komattil R. (2015). Acquisition of Knowledge, Generic Skills and Attitudes through Problem-Based Learning: Student Perspective in a Hybrid Curriculum.Jurnal Pendidikan Journal of Taibah University Medical Sciences. 10(1), 21-25
[6] Liliasari. 2007. Scientific Concepts and Generic Science Skills Relationship in the $21^{\text {st }}$ Century Science Education. Seminar Proceeding of the First Internasional Seminar of Science Education. 27 oktober 2007. Bandung. 13-18.

[7] Marcer-Mapstone L., Kuchel. 2017. Core skills for effective science communication: a Teaching resource for ungraduated acience education. International Journal of Science Education.Part B 7(2). 181-201.

[8] Miles., M.B \& Huberman, A.M. 1995. Analisis Data Kualitatif, Terj. Tjetjep Rohendi Rohidi. Jakarta: UI-Press.

[9] Mulyani Sumantri dan Johan Permana.2001.Strategi Belajar Mengajar. Bandung: CV.Maulana.

[10] Peraturan Menteri Pendidikan dan Kebudayaan Republik Indonesia Nomor 160 Tahun 2014 Tentang Pemberlakuan Kurikulum 2006 dan Kurikulum 2013.

[11] Sudarmin. (2012). Keterampilan Generic Sains dan Penerapannya dalam Pembelajaran Kimia Organik. Semarang: Universitas Negeri Semarang 